\title{
江戸川放水路トビハゼ人エ干潟の 10 年 \\ 10 YEARS FIELD SURVEY OF MUDSKIPPERS IN ARTIFICIAL TIDAL FLAT OF EDOGAWA CANAL
}

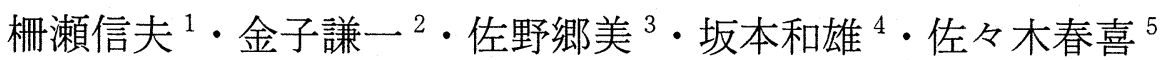 \\ Nobuo SAKURAI, \\ Kenichi KANEKO, Satomi SANO, Kazuo SAKAMOTO and Haruki SASAKI \\ ${ }^{1}$ 正会員 鹿島建設技術研究所 葉山水域環境研究室 （下240-0111 神奈川県三浦郡葉山町一色 2400） \\ 2市川市市川自然博物館（广272-0881 千葉県市川市大町 284） \\ 3 千葉県立市川西高等学校 （下272-0833 千葉県市川市東国分 1-1） \\ ${ }^{4}$ 国土交通省関東地方整備局江戸川工事事務所 （广278-0005 千葉県野田市宮崎 134） \\ ${ }^{5}$ 国土交通省関東地方整備局（テ330-9724 埼玉県さいたま市北袋町 1-21-2）
}

\begin{abstract}
To determine habitat feasibility of mudskipper in artificial tidal flat, ecological studies on mudskipper in the site were carried out for 10 years. Number of the spawning burrow was observed yearly as an indicator for evaluating their habitat feasibility. The spawning burrow increased after 5 years surveying (100-200 burrows). The survey results concluded that the artificial tidal flat could be a sustainable habitat space for mudskipper.
\end{abstract}

Key Words : $\quad$ Mudskipper, artificial tidal flat

\section{1. はじめに}

千葉県市川市の江戸川放水路西岸中央部は，1990 年の台風 19 号の波浪によって $850 \mathrm{~m}$ にわたて護岸 沈下を生じた（図一1）。このため，旧建設省江戸川 工事事務所は，沈下の復旧事業として，上流側 350 $\mathrm{m}$ を高水敷にし，その護岸はコンクリートブロック を設置する改修工事を行った。この後, 残り $500 \mathrm{~m}$ の工事計画段階で, 計画区間前面に潮が引くと現れ る干潟に生息するトビ八ゼ (Periophthalmus modestus）の保護の要望が地元住民から出された. この要望に江戸川工事事務所では, 護岸工事とトビ 八ゼ保護の両立を目標に, 当地のトビ八ゼ研究者に 協力を求め, 同地の行徳可動堰下流部のトビハゼが 生息する天然干潟をモデルにした人工干潟を創造し, （図一2)これを基に設計変更が行われ工事が実施さ れた. 1992 年完成した人工干潟には, 工事前に保護 し，飼育したトビ八ゼが放流され，トビ八ゼ保護を 目的とした護岸復旧事業が完了した ${ }^{1,2), 3)}$.

建設工事と生物の共生が言われている現在, 10 年 前に実施された工事による代替地の造成, 人工干潟
が本当にトビ八ゼを救うことができたのかを知る目 的で，トビ八ゼの干潟利用と生息を確認する調査に ついて, 今回は人工干潟造成事業完了から 2001 年に 至る 10 年間の経過を報告する (写真 -1$)$.
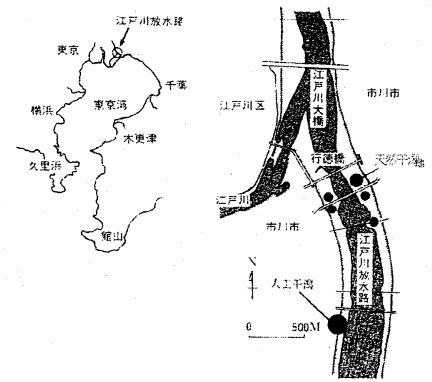

図-1 調查地点

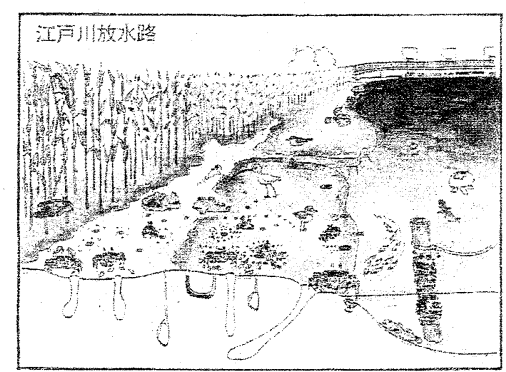

図ー2 モデル 


\section{2. 人工干潟造成}

護岸改修とトビハゼの生息環境創造を目的に以下 の設計変更を行った (図-3） ${ }^{1), 2,3)}$.

この計画で造成した人工干潟部分は，延長 $460 \mathrm{~m}$ ， 幅 $12.5 \mathrm{~m}$ を有し, 天然干潟と同様に干潟中央部地盤 高は平均潮位より $20 \sim 30 \mathrm{~cm}$ の潮高にあり, 大潮時に は干潟全体が 8 時間程度干出する ${ }^{4), 5)}$. 沖岸に消波 用蛇力ゴ， 6 個一組 $(8 \mathrm{~m} \times 2 \mathrm{~m} \times$ 高さ $1 \mathrm{~m})$ を $3.5 \mathrm{~m}$ 間隔で 40 個設置した. 改修前と同様, 杭を蛇力ゴ後 背部に $2 \mathrm{~m}$ 間隔で全延長に設置し，ハゼ釣りボート 進入を防止した. 1992 年には仮設置した底泥を干潟 に敷き，護岸にはヨシが植栽され，同年 4 月に計画 通り人工干潟が完成した。 1992 年 6 月, 保護飼育し たトビ八ゼ 860 個体のうち, 生存した 86 個体を人工 干潟に放流した (写真 $-2 \mathrm{a})^{3)}$.

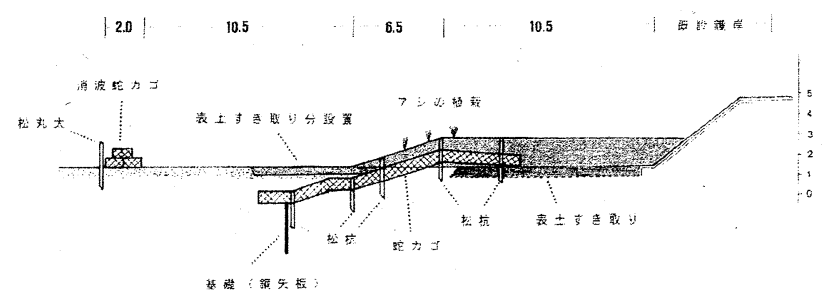

図-3 江戸川放水路第二期護岸断面図
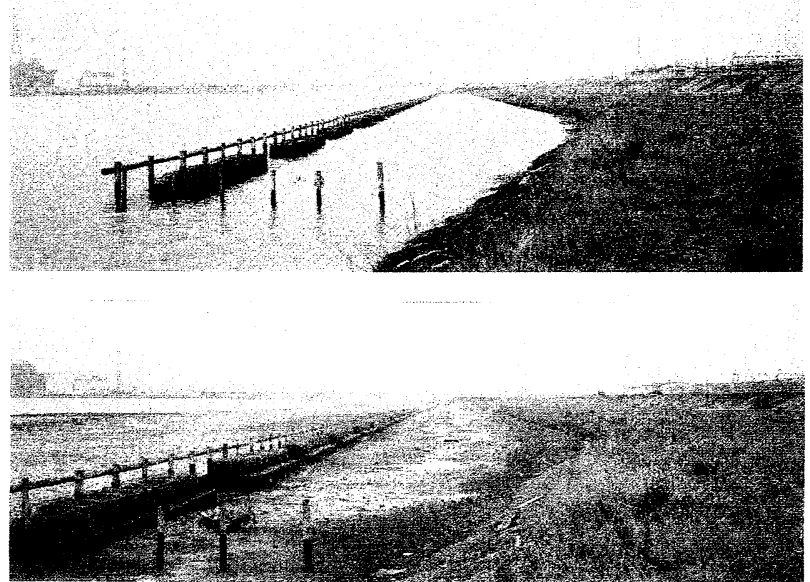

写真 -1 人工干潟の干満

\section{3. 調査期間および調査項目}

設計変更がトビ八ゼにとって適正であったかを評 価するために調査は, 1992 年 6 月の放流時点から開 始し, 改修前の干潟との比較をするための調査を含 めると 1991 年から 2001 年までの 11 年間に至る.そ して, 調査時期はトビ八ゼの産卵期に当たる 7 ８ 月を中心に行った。

調査地点と調査項目は, 人工干潟前面を下流から
上流に向かって $50 \mathrm{~m}$ 間隔で 9 区分し,最上流部を $\mathrm{A}$, 最下流部を I とした。 区分した干潟横断面線上に護 岸から沖側に向かって護岸下の露出した杭（st.1） を基点に, $3 \mathrm{~m}$ 先 (st. 2), $6 \mathrm{~m}$ 先 (st. 3), $9 \mathrm{~m}$ 先 (st. 4), 大杭下 $12 \mathrm{~m}$ (st. 5)，大杭外 $17 \mathrm{~m}$ 先 (st.6) を観察 点とした (図-4)。この観察点では, 干潟の地盤 変化を知るための高さ測定を全観察点で行い，底質 の変化を知るための粒度分布と含水率を求める採泥 を各区分のst. 2,3,4,6で行った。

護岸の浸食状況を観察するため, 40 ある各蛇カゴ の中心部分に対面した護岸崩落部分を測定し，ヨシ の生育群落状況も蛇力ゴを基本に観察した. 1991 年 から 2001 年に至る調査項目と概要を表一 1 に示した. 本調査の目的であるトビ八ゼの産卵用巣穴の観察と 記録は，前述の観察点と蛇カゴとの位置を組み合わ せて位置設定した。蛇力ゴは最上流部を No. 1, 最下 流部を No. 40 とした.

\section{表-1 年次別調查項目}

\begin{tabular}{|c|c|c|c|c|c|c|c|}
\hline $\begin{array}{l}\text { 項 } \\
\text { 年 } \\
\text { 次 }\end{array}$ & $\begin{array}{l}\text { 干 } \\
\text { 潟 } \\
\text { 構 } \\
\text { 造 }\end{array}$ & $\begin{array}{l}\text { 生 } \\
\text { 物 } \\
\text { 観 } \\
\text { 察 }\end{array}$ & $\begin{array}{l}\text { トビハゼ } \\
\text { 産卵巣穴 }\end{array}$ & $\begin{array}{l}\text { 地 } \\
\text { 盤 } \\
\text { 高 }\end{array}$ & $\begin{array}{l}\text { 底 } \\
\text { 質 }\end{array}$ & $\begin{array}{l}\text { 水 } \\
\text { 温 } \\
\text { 分 } \\
\text { 分 }\end{array}$ & $\begin{array}{l}\text { 開 } \\
\text { 放 } \\
\text { 状 } \\
\text { 態 }\end{array}$ \\
\hline 1991 & 0 & 0 & 0 & & 0 & & \\
\hline 1992 & $\begin{array}{l}\text { 護岸状況 } \\
\text { ヨシ成育 }\end{array}$ & (a) & 0 & 0 & 0 & & \\
\hline 1993 & & 0 & 0 & 0 & 0 & & \\
\hline 1994 & (0) & (0) & 0 & 0 & 0 & (a) & \\
\hline 1995 & 0 & 0 & 0 & 0 & 0 & & \\
\hline 1996 & (0) & (2) & 0 & 0 & 0 & () & \\
\hline 1997 & 0 & 0 & 0 & 0 & 0 & & \\
\hline 1998 & (0) & (0) & 0 & 0 & 0 & (2) & (2) \\
\hline 1999 & 0 & 0 & 0 & 0 & 0 & & \\
\hline 2000 & 0 & 0 & 0 & 0 & 0 & & \\
\hline 2001 & (0) & (2) & 0 & 0 & 0 & (a) & \\
\hline
\end{tabular}

○年次重点項目

\section{4. 調査結果}

\section{（1）地盤変化}

地盤の判定は，人工干潟を区分するために設置し た, 杭の天端が全延長で一定の高さを保つため, こ の天端を基点に水糸を張り, 護岸下の露出した杭部 分に棒を立てたものに結び水平をとり，この水系と 地盤の距離を測定し, 地盤高とした。測定は観察点 区分 $\mathrm{A} \sim \mathrm{I}$ の st. 1〜6に渡る 54 点とした. 


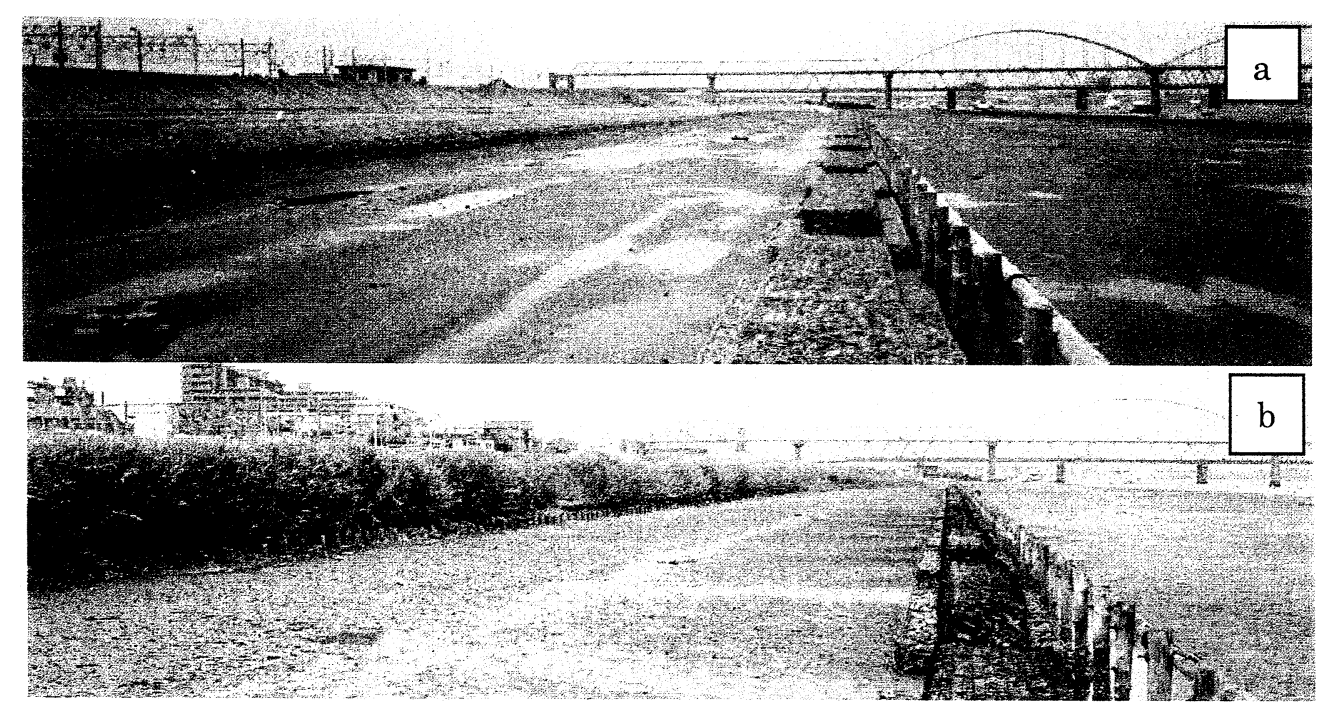

写真－2 1992 年(a)と 2001 年(b)の状況

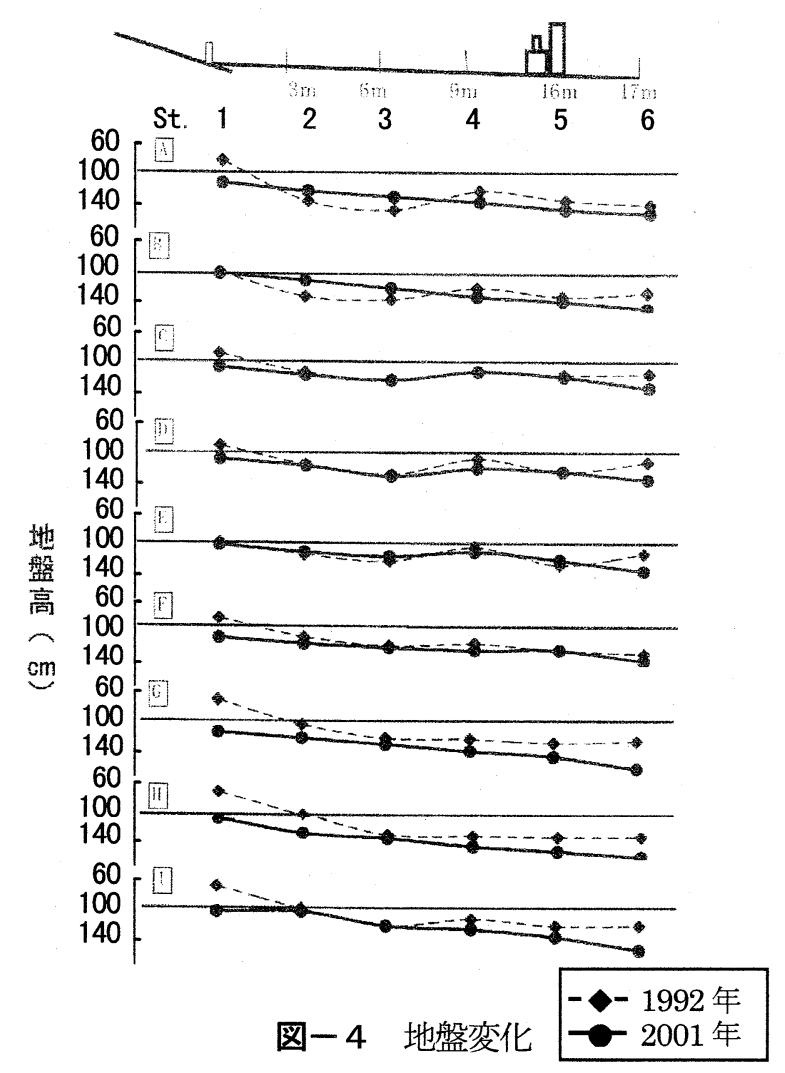

地盤の変化を造成直後の 1992 年 6 月と 10 年後の 2001 年 7 月の測定值で比較した（図-4）。1992 年 の値に対し, 部分的には 10 20 cm 程度の上昇は認め られたが, 全体は平均 $10 \mathrm{~cm}$ 程度の低下もしくは 92 年の值に近いものを示し，造成時に設定した地盤の 潮高に対し，大きな変化はなかった。護岸下の低下 は，浸食によるもので，C，D，Eのst. 3 は谷を形成 し, 実際には湧水を源にしたミヨ筋となっている(写 真 -2, b ) . 全ての観察点 st. 5 は蛇カゴと蛇カゴと の中間部分で潮の満ち引きに伴って常に水が通過す るため蛇力ゴ中央部より低くなっている。そして,

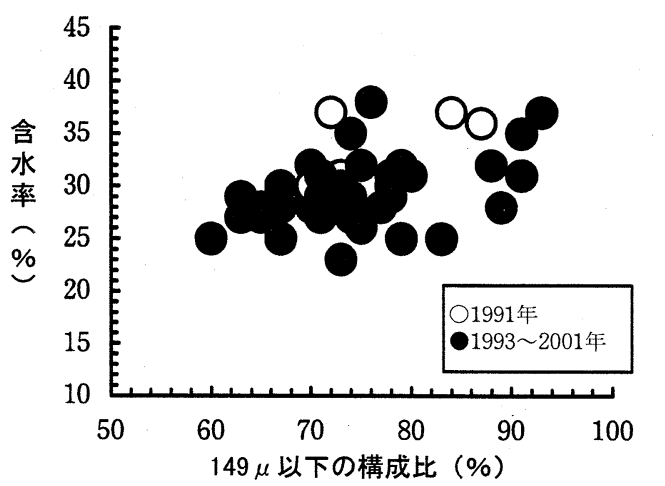

図－5人工干潟巣穴の含水率と底質粒子の関

1996 年からは，カゴ中央を頂点にしてなだらかな泥 の堆積が起こり, 2001 年では, 最大 $25 \mathrm{~cm}$ 程度の高 い部分が出現し, この傾向は全体の蛇カゴに見られ た（写真 -3$)$.

また, 1994 年 8 月下旬から 10 月にかけて放水路 でのハゼ釣りの釣餌であるゴカイの採集が始まり， それは現在まで続いている。そして，この1ヶ月で 干潟全面が掘り出され, そのため小さな凹凸と水溜 りが干潟表面に点在し，これをトビ八ゼの成魚, 稚 魚が利用していた。しかし，次年の春にはこの凹凸 水溜りは消失し, 元の平坦な干潟に戻った。

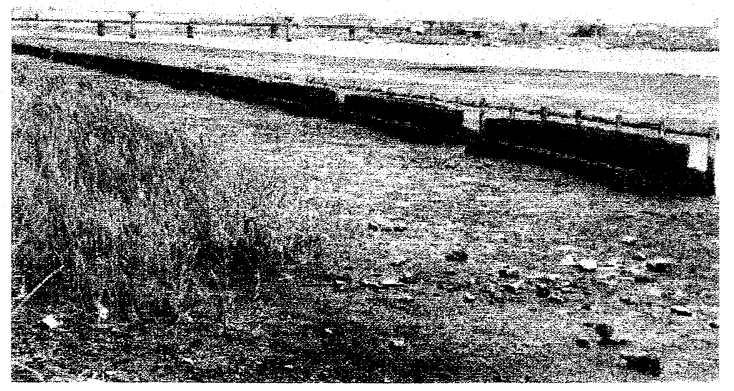

写真-3 蛇カゴへの堆積 


\section{（2）含水率}

上流の天然干潟でのトビハゼ産卵用巣穴での底質 含水率は $25 \%$ 以上を示し ${ }^{5}$, 改修前と人工干潟での 2001 年まで, 合計 58 箘所の産卵用巣穴の底質含水 率は 20\%以上を示した（図－5）。1992 年から 2001 年までの 10 年間の含水率の変化は, 全体では大きな 変化はなく, 一部を除いて多くの観察点の含水率は 20\%以上を示し, 営巣の条件範囲にあった。部分的 には護岸部分から涌き出す水が一筋のミヨをつくり, このミヨ筋に当たる部分で高い含水率があった。

\section{（3）底質}

上流の天然干潟でのトビハゼ産卵用巣穴の底質粒 子構成で $149 \mu$ m以下の泥分が $60 \%$ 以上を示し 5), 改修前と人工干潟での 2001 年まで合計 58 ヶ所の産 卵巣穴の底質粒子構成でも $149 \mu \mathrm{m}$ 以下の泥分が $60 \%$ 以上を示していた（図－5）。1992 年から 2001 年までの 10 年間の底質粒子構成における $149 \mu \mathrm{m}$ 以下の泥分の変化は, 人工干潟造成完了時の 1992 年には干潟の広い範囲で $60 \%$ に近いか，それを超え
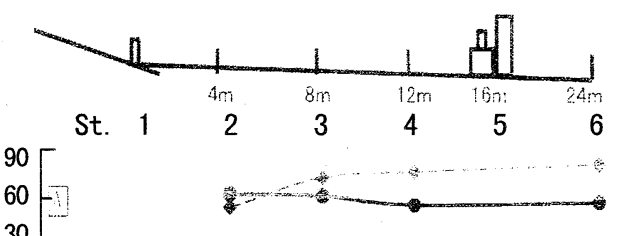

St.

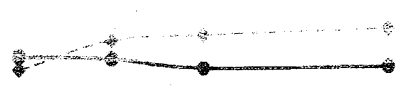

$30 \mathrm{~L}$

90
60
30 [

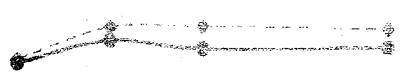

90[

30

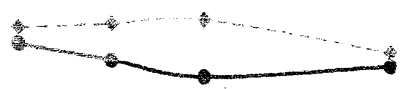

90

$6 0 \longdiv { 1 }$

$30 L$

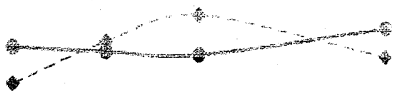

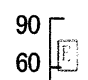

$30 L$

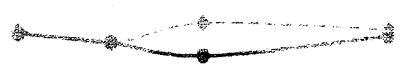

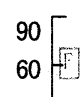

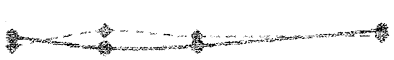

(\%) 60 \%

90
60
30 $[$ [
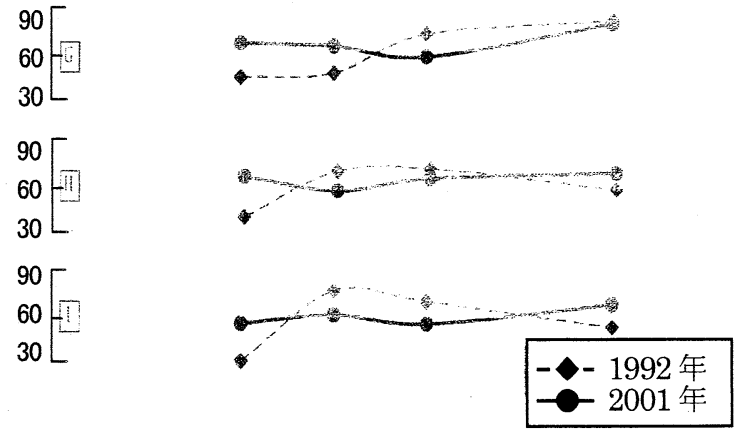

図-6 底質粒子 $149 \mu \mathrm{m}$ 以下の変化
る値を示し，その結果，人工干潟全体面積の 6 割か

ら 7 割近くが営巣可能な底質となった（図一6）.

また, 蛇カゴの中央部分に堆積した泥のうち, 蛇 カゴNo.11〜13 では砂質が多く, ここではチゴガニ が営巣し，他とは異なる状況を示した。

\section{（4）護岸浸食}

土で化粧した護岸は，1992 年 6 月には護岸下の杭が 露出する状態が起こり, 1993 年には大規模に浸食される 部分が発生した（写真－4）。この浸食状況を知るため に 1994，1996，1998，2001 年に各蛇カゴに対面した護 岸の浸食断面を測定した。 その結果を断面積として図一 7 に示した.

大きな浸食のあった蛇カゴNo.25〜32 の部分は, 改修 のきっかけとなった台風の護岸沈下が著しい場所と一致 していた. またこの前面の蛇カゴは, 変形し杭も消失し ている部分があり, 干潟全体で最も波浪の影響を強く受 けていることを示していた，そして 1998 年以降，この 部分を含めて全体の浸食は大きくなった．またヨシの成 育によって, 護岸全体に根が張り, その結果土留めの役 割を果たしている反面, 根の成長で崩落をまねいている 部分もある（写真-5）。

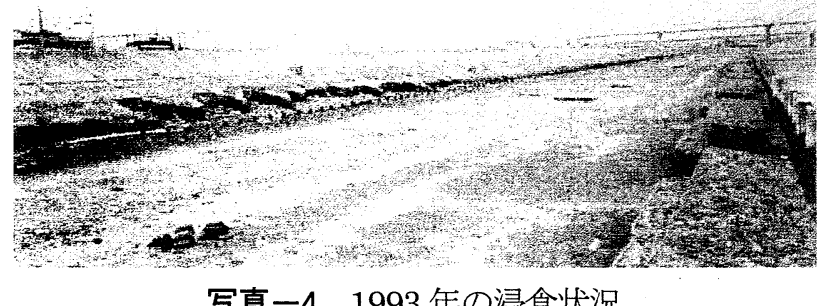

写真－4 1993 年の浸食状況
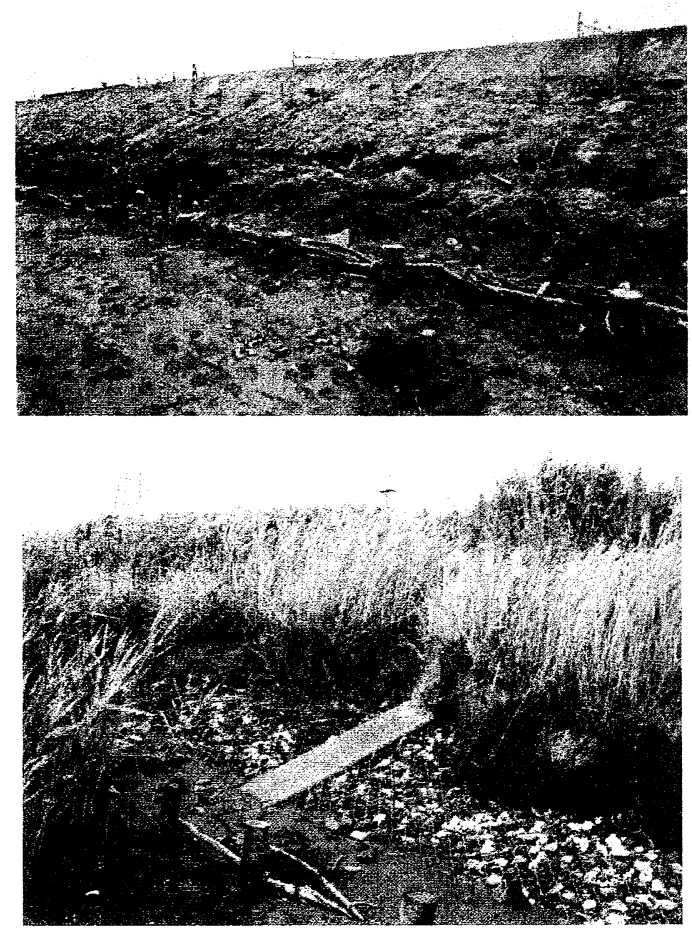

写真－5 護岸の状況（上段 1992 年、下段 2001 年） 
浸食断面積 $\left(\mathrm{m}^{2}\right)$

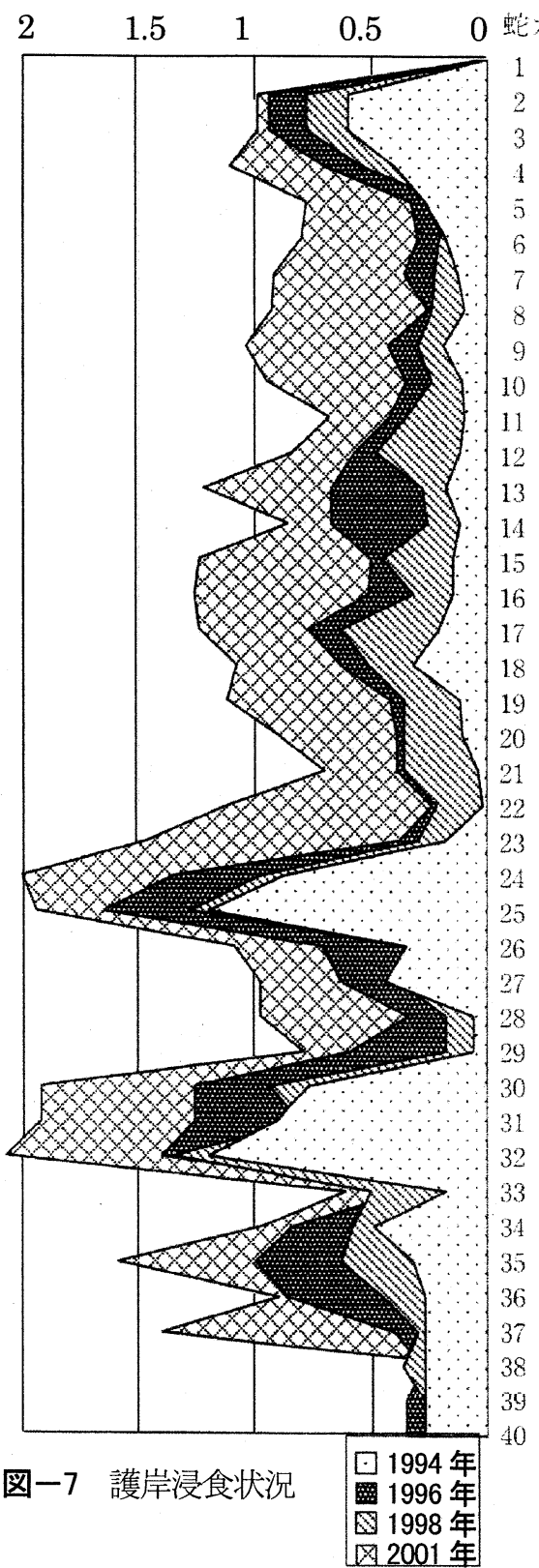

護岸の浸食崩落による干潟への影響は, 護岸を構成す る土質の泥分が $80 \%$ 以上含む土丹が 60 〜 70\%を占め, これが崩落し水に溶け，干潟一の泥分補給を行った可能 性が強い. その理由は, 1991 年 10 月 12 日から 1998 年 8 月 30 日まで放水路行徳可動堰開放はなく, 江戸川 上流からの泥分の補給は全くない状況が人工干潟完成後 7 年間続き, この期間の泥分の維持は, 護岸の浸食崩落 によると考えられる。

\section{（5）ヨシの成育}

護岸上部に 2 列のヨシ類の植裁を施した. この植栽を 含めて, 1996 年には, 浸食部分を除いて, ヨシ類の成育 が見られ，高水敷部分もヨシ類の群落が広がった．そし て，1998年には，その全体を占め，夏期は大人の背の高 さまで頂した（写真 $-2 \mathrm{~b}$, 写真 -5 下段）。

干潟上には, 1997 年から一部が成育しはじめ, 1998,
99 年と徐々に拡大し, 2001 年では, 蛇カゴNo.29 31 に対面する部分では，干潟の中央部までに頂し，それよ り下流は, 護岸に沿って巾 $4 \mathrm{~m} の ヨ シ$ 群落が形成された. また, 蛇力ゴNo.4，5に対面した護岸下にも小さな群落 が出現し拡大する方向にある。

\section{（6）可動堰開放による影響}

1998 年 8 月 30 日と 9 月 16 日前後に江戸川本流の洪 水による水位上昇で行徳可動堰が開放され，放水路は川 水が流下した。 この流下によって, 放水路内の干潟上に 川水に含まれた泥分が $0.5 \sim 1 \mathrm{~cm}$ 程度堆積し, 特に $75 \mu$ m以下のシルトの補給が示された（図一8）。この泥分 の補給によってか, 1999 年から放水路全体の産卵用巣穴 数が年々増加している.

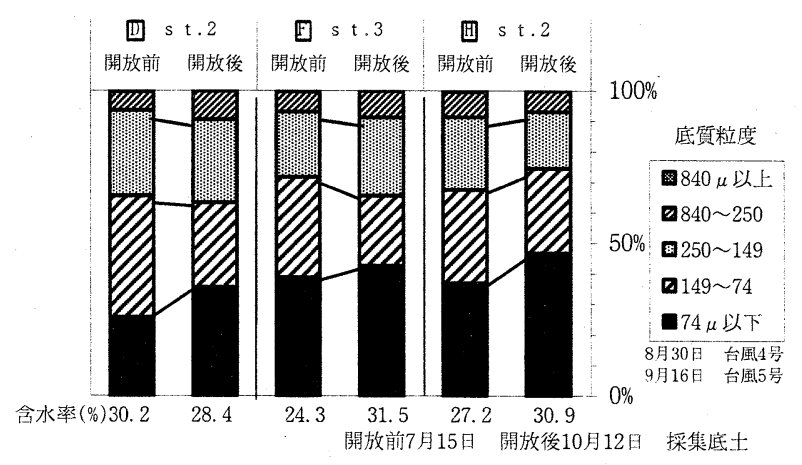

図－8 1998 年可動堰開放前と後の底質状況

\section{（7）産卵巣穴数}

広い干潟では, 活動するトビ八ゼの正確な個体数を得 ることは経験上難しい，そこで個体数に代わって 6〜8 月に成魚が掘った産卵用巣穴を指標として，その数を調 查した（写真－6）。干潟上には，トビ八ゼの巣方以外 で類似したヤマトオサガニ等のカニ穴が点在するため, 巣穴並びにその周辺の形状からトビ八ゼの巣穴だけを識 別し，それを記録した。その記録を基に 1993 年から 2001 年に至る巣穴数の実数と $\mathrm{m}^{2}$ 当りの個数に、天然干潟での 記録を加えたものを表一2に示した。人工干潟 $5520 \mathrm{~m}^{2}$, 天然干潟 $22650 \mathrm{~m}^{2}$ の異なる面積下で, 1996 年以降, $\mathrm{m}^{2}$ 当り個数は天然干潟に近い值を示し, 各年での個体の増 減状況も同様であった。

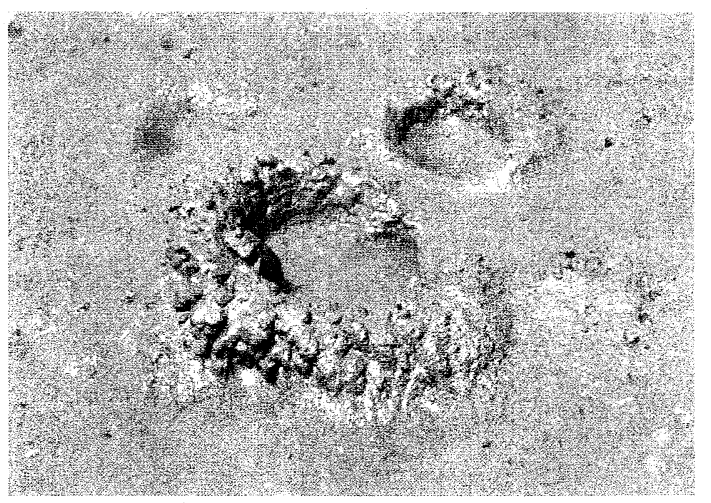

写真-6 トビ八ゼと巣穴 
表-2 産卵巣穴調査結果

\begin{tabular}{|c|c|c|c|c|c|c|c|c|c|c|}
\hline & 1993 & 1994 & 1995 & 1996 & 1997 & 1998 & 1999 & 2000 & 2001 & 巣穴合計 \\
\hline 人工干潟 & 16 & 9 & $\begin{array}{c}187 \\
(0.03)\end{array}$ & $\begin{array}{c}111 \\
(0.02)\end{array}$ & $\begin{array}{c}39 \\
(0.00)\end{array}$ & $\begin{array}{c}104 \\
(0.02)\end{array}$ & $\begin{array}{c}79 \\
(0.01)\end{array}$ & $\begin{array}{c}175 \\
(0.03)\end{array}$ & $\begin{array}{c}238 \\
(0.04)\end{array}$ & 958 \\
\hline 天然干潟 & & & $\begin{array}{c}1441 \\
(0.06)\end{array}$ & $\begin{array}{c}683 \\
(0.03)\end{array}$ & $\begin{array}{c}312 \\
(0.01)\end{array}$ & $\begin{array}{c}376 \\
(0.02)\end{array}$ & $\begin{array}{c}513 \\
(0.02)\end{array}$ & $\begin{array}{c}767 \\
(0.03)\end{array}$ & $\begin{array}{c}940 \\
(0.04)\end{array}$ & 5032 \\
\hline
\end{tabular}

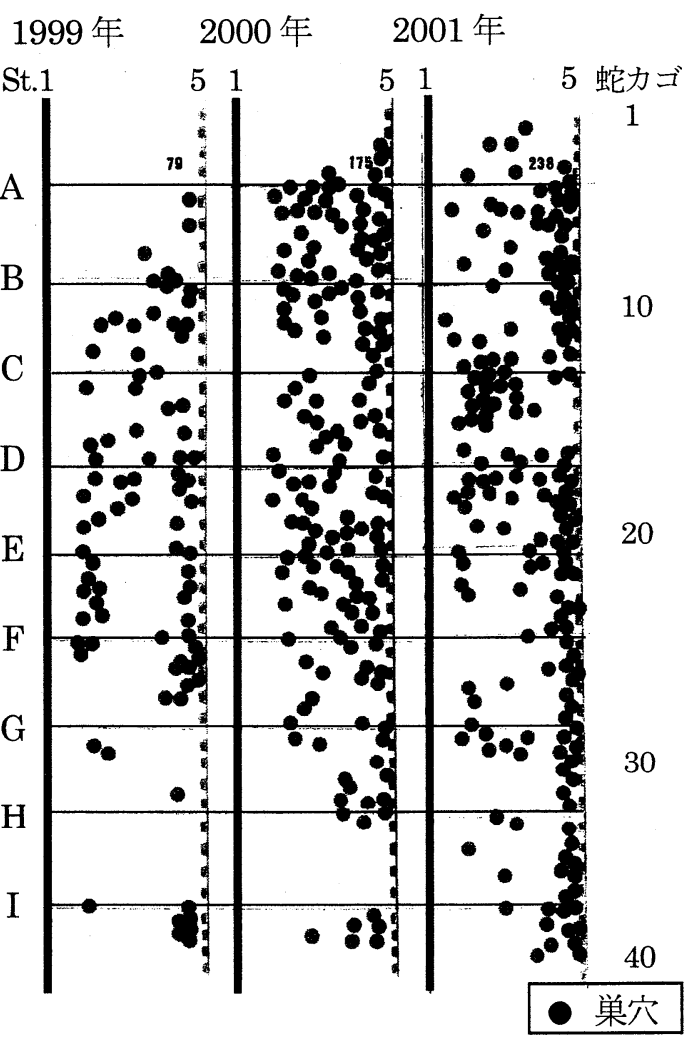

図－9 1999 2001 年の巣穴分布模式図

干潟上での巣穴の位置は, 1999 年から先に述べた蛇力 ゴに堆積した底泥に巣穴が集中する傾向が始まり 2001 年では多くの巣穴が蛇カゴに集中していた（図一9）。 この集中する傾向は，営巣するために適した底泥が堆積 したことと, トビ八ゼの捕食者である水鳥や，追いまわ す人間からの待避場所として，蛇カゴを利用することを 学習した可能性がある.

\section{5. まとめ}

人工干潟は, 天然干潟をモデルに造成し，10 年経過し た時点で天然干潟と同等の姿があった (図 -2 , 写真 -2 b）。それは，放水路内で最も波当りが強い場所を予想 し, 干潟沖岸に充分な消波用蛇カゴを設置したことで, 平均潮位より高い地盤が維持され，構造的な大きい変化
（ ） $\mathrm{m}^{2}$ 当りの個数

が起こらなかったことに起因している.

また計画では, 行徳可動堰の開放による川水に含まれ る泥分が干潟の底泥維持に役立つと考えていた. しかし 可動堰の開放は完成後 7 年間は全くなく, その代わり護 岸の浸食崩落したものが泥分補給に役立っていた。 この 泥分は, 多数のトビ八ゼが底泥中に産卵用巣穴をつくり, そこで産卵ふ化を行い，冬期にはこの底泥中で冬眠でき る $149 \mu \mathrm{m}$ 以下のシルトを多く含む泥分が $60 \%$ 以上常 に存在し，それは天然干潟の生息条件と一致していた.

人工干潟の状況変化に一番関心を示したのが子供達で, 1994 年には干潟に入ってトビ八ゼやカニを追って楽し い時間を過していた．また，同年には干潟を掘ってゴカ イを採る人が現われ，毎年干潟を耕すことで地盤の硬化 を防ぎ，トビ八ゼの餌料でもあるゴカイやカニ類の増加 の一助になっている。 その反対にトビ八ゼを捕食するた めに飛来する水鳥など被・捕食関係がひとつの干潟上で 形成され，それはトビ八ゼを中心に，多種の生物が生息 していることを示していた.

トビ八ゼが生息する東京湾内の数少ない干潟の内，大 田区東京港野島公園夘入池，江戸川区葛西海浜公園東人 工渚のように人工造成した場所でも, トビハゼの生息個 体数が増加している. この状況から人工的なものでも, 条件が整えばトビ八ゼは生息し増殖する能力が有り, 10 年経過した江戸川放水路の人工干潟は, その能力を充分 引き出すことに成功している.

\section{参考文献}

1）(財)河川情報センター：新・川物語 1 , トビハゼ 所長奮闘記, p p.1-7, 1992.

2) 磯部雅彦(編): 海岸の環境創造, 朝倉書店, p p.40-73, 1994.

3）柵瀬信夫 : 環境教育と護岸改修, 第 2 回地球環境 シンポジューム講演集, 土木学会, p p .245〜250, 1994.

4）柵瀬信夫ほか：干潟の生態に関する研究(1), 鹿島 技術研究所年報，39，p p.335-342，1991.

5）柵瀬信夫ほか：江戸川放水路トビ八ゼ生息干潟の 特性, 海洋開発論文集, vol. 16, p p .357 362, 2000. 